\title{
POPULATION AND SPATIAL DEVELOPMENT OF SETTLEMENTS IN LJUBLJANA URBAN REGION AFTER 2002
}

\author{
Dr. Dejan Rebernik \\ Department of Geography, Faculty of Arts, University of Ljubljana \\ Aškerčeva 2, SI-Ljubljana \\ e-mail: dejan.rebernik@guest.arnes.si \\ Original scientific article \\ COBISS 1.01 \\ DOI: $10.4312 /$ dela.42.4.75-93
}

\begin{abstract}
The paper is analysing spatial and population development of settlements in Ljubljana Urban Region after 2002. On the basis of population change we determined the main urbanisation processes in the region. To the end of 1970s fast population growth was due to immigration from rural parts of Slovenia and the rest of Yugoslavia. In the 1980s and 1990s deconcentration of population within the region with intense suburbanisation were the main processes. After 2002 the fastest population growth was in in the rural hinterland. Dispersed settlement pattern with all negative implications of urban sprawl is thus characteristic.
\end{abstract}

Key words: settlement, population change, urbanisation, suburbanisation, periurbanisation, urban sprawl, Ljubljana, Ljubljana Urban Region, population geography

\section{RAZVOJ PREBIVALSTVA IN URBANIZACIJSKI PROCESIV LJUBLJAN- SKI URBANI REGIJI PO LETU 2002}

\section{Izvleček}

Prispevek analizira prostorski in prebivalstveni razvoja naselij v Ljubljanski urbani regiji po letu 2002 in opredeljuje poglavitne urbanizacijske procese. Sprva je bila hitra rast prebivalstva zaradi priseljevanja iz ruralnih delov Slovenije in republik bivše Jugoslavije, pozneje sta prevladovali dekoncentracija prebivalstva in intenzivna suburbanizacija. Po letu 2002 je najhitrejša rast prebivalstva v ruralnih naseljih v zaledju. $\mathrm{Na}$ ta način je suburbanizacija prešla $\mathrm{v}$ periurbanizacijo, zato je značilna razpršena poselitev $\mathrm{z}$ vsemi negativni posledicami urban sprawl.

Ključne besede: naselje, razvoj prebivalstva, urbanizacija, suburbanizacija, periurbanizacija, Ljubljana, Ljubljanska urbana regija, geografija prebivalstva 


\section{INTRODUCTION}

Ljubljana and its urban region is the main central area in Slovenia. As the political and economic center of Slovenia and its main employment center, Ljubljana attracted strong immigrations, mostly from rural and less developed parts of Slovenia and the rest of Yugoslavia. This resulted in fast population growth in the period after 1945. Immigrants provided labor force for developing manufacturing and services. Till the end of the 1970s, pronounced concentration of population in Ljubljana and its 'satellite' towns (Domžale, Kamnik, Medvode, Vrhnika, Logatec and Litija) was typical. In the 1980s and 1990s, deconcentration of population within the region with intense suburbanisation and depopulation of inner city and older residential neighborhoods in Ljubljana were the main urbanisation processes. After 1991 Ljubljana became a capital of Slovenia and the whole region recorded a very dynamic economic growth, which attracted new immigrations to the region. As the most developed region with the best development possibilities in the country, Ljubljana attracted young and highly qualified work force (Rebernik, 2005). In the second half of the 1990s, the highest population growth was recorded in dispersed rural settlements in the periphery of the region. Urbanisation of rural parts of the region had all the characteristics and negative effects of the 'urban sprawl'.

The main purpose of the paper is to present and delineate characteristics of population and spatial development of settlements and urbanisation processes in Ljubljana Urban Region (LUR) after 2002. On the basis of typology of settlements according to urbanisation processes developed by Ravbar (1997), the region can be divided into towns, nearby suburbs, suburbanised settlements and rural settlements. We attempted to determine whether there are differences in the population change and spatial development of settlements among the areas so defined. We were also interested in whether there were any important changes in population development compared to the period before 2002. In our research we examined population development of settlements between 1991, 2002 and 2012. The delineation of processes of population development and urbanisation trends in this period is based on comparison of the number of inhabitants by municipalities and settlements. Maps with indexes of population change between 1991, 2002 and 2012 were the basis for this comparison. Special attention was put on population development of different types of settlements defined by Ravbar (1997).

A research of population and spatial development of settlements in LUR before 2002 was done by Ravbar (2002) and Rebernik (2005). As in Slovenia suburbanisation is also accompanied by intensive morphological, functional, and socio-economic transformation of settlements, we attempted to identify the basic characteristics of morphological and socio-economic transformation of settlements.

\section{URBANISATION TRENDS IN SLOVENIA}

In Slovenia, the urbanisation level is relatively low in comparison with other European countries, just about $50 \%$. Despite of this, from the 1950s to 1970 s, fast growth of urban population was characteristic. Urbanisation level grew from $26 \%$ in 1948 to $35 \%$ 
in $1961,45 \%$ in 1971 and $49 \%$ in 1981 . Average growth of urban population per year reached 2.15\% between 1961 and 1971 and 2.05\% between 1971 and 1981, whereas general population growth reached only $0.6 \%$ in the first and $1.1 \%$ in the second period (Ravbar, 1995). Urbanisation was mainly the result of deagrarisation and industrialisation and of rural-urban migrations from Slovenia and the rest of Yugoslavia. The fastest population growth was recorded in bigger regional centers, such as Ljubljana, Maribor, Celje, Kranj, Koper and Novo mesto and in predominantly manufacturing towns such as Jesenice, Trbovlje and Tržič. In the 1970s and 1980s, the fastest population growth was recorded in urban areas, but at the end of this period suburbanisation took place as well. However, it has to be pointed out that the urbanisation in Slovenia was less intensive than in other former Yugoslav republics. This is a consequence of very strong daily migrations of rural population to urban employment centers and the beginning of implementation of polycentric urban and economic development. In the 1970s and 1980s, polycentrism has become the main concept of urban and regional planning. The creation and development of employment and services in smaller urban and rural central places was encouraged. In this way, dispersed industrialisation and good accessibility to employment slowed down rural-urban migrations (Rebernik, 2005).

After 1981, urban growth slowed down considerably. Urbanisation level reached 51\% in 1991, but average growth of urban population per year $(0.8 \%)$ was slower than general population growth (1.0\%; Ravbar, 1995). In this period most towns had low population growth, but for the first time several urban centers, mostly larger, recorded negative population growth. In this way, in the 1980s urbanisation with concentration of population in urban centers passed to suburbanisation of urban regions around larger cities. On the account of out-migration of urban population, the fastest population growth was recorded in suburban areas around main regional centers. Suburbanisation was most intense in urban regions of Ljubljana, Maribor, Celje, Kranj, Koper and Nova Gorica.

In the 1990s, these processes became even more pronounced. Total number of urban population in Slovenia declined the most in larger cities. Between 1996 and 2002, the highest loss of population was thus recorded in Maribor $(-6,000)$, Ljubljana $(-5,900)$, Jesenice $(-4,300)$, Nova Gorica $(-1,200)$, Celje $(-1,100)$ and Murska Sobota $(-1,000)$. In this way the percentage of population living in urban areas dropped for $1 \%$ between 1996 and 2002 (Rebernik, 2005). Deconcentration of population within urban regions continued. In the first half of the 1990s, the fastest population growth was recorded in suburban settlements, whereas in the second half of the decade small rural settlements with good accessibility had the fastest growth.

In the period after 2002 similar trends continued. Population growth was most pronounced in suburban and rural settlements around larger urban centers (Ljubljana, Maribor, Celje, Koper, Nova Gorica and others). After 2005 some interesting changes in population development can be observed. In some larger urban centers (Ljubljana, Maribor, Kranj, Koper and Novo mesto) population growth was recorded after a longer period of population decline. This process is the result of redevelopment of derelict urban areas, more intensive housing construction and 'inner development of settlements' and can be described as reurbanisation. 


\section{MAIN CHARACTERISTICS OF SETTLEMENT STRUCTU- RE IN LJUBLJANA URBAN REGION}

Ljubljana Urban Region is one of twelve Slovenian development statistical regions as were defined by the Decree on the standard classification of territorial units. Together with municipalities, statistical regions are basic territorial units for collecting, processing and analysing statistical data. They are used as main units in implementing regional policy and in harmonisation of Slovenian regional policy with regional policy of European Union. In this regard, statistical regions are responsible for elaboration and implementation of regional development programs (Rebernik, 2005).

Figure 1: Population density in Ljubljana Urban Region by settlements (2012)

Slika 1: Gostota prebivalstva v Ljubljanski urbani regiji po naseljih (2012)

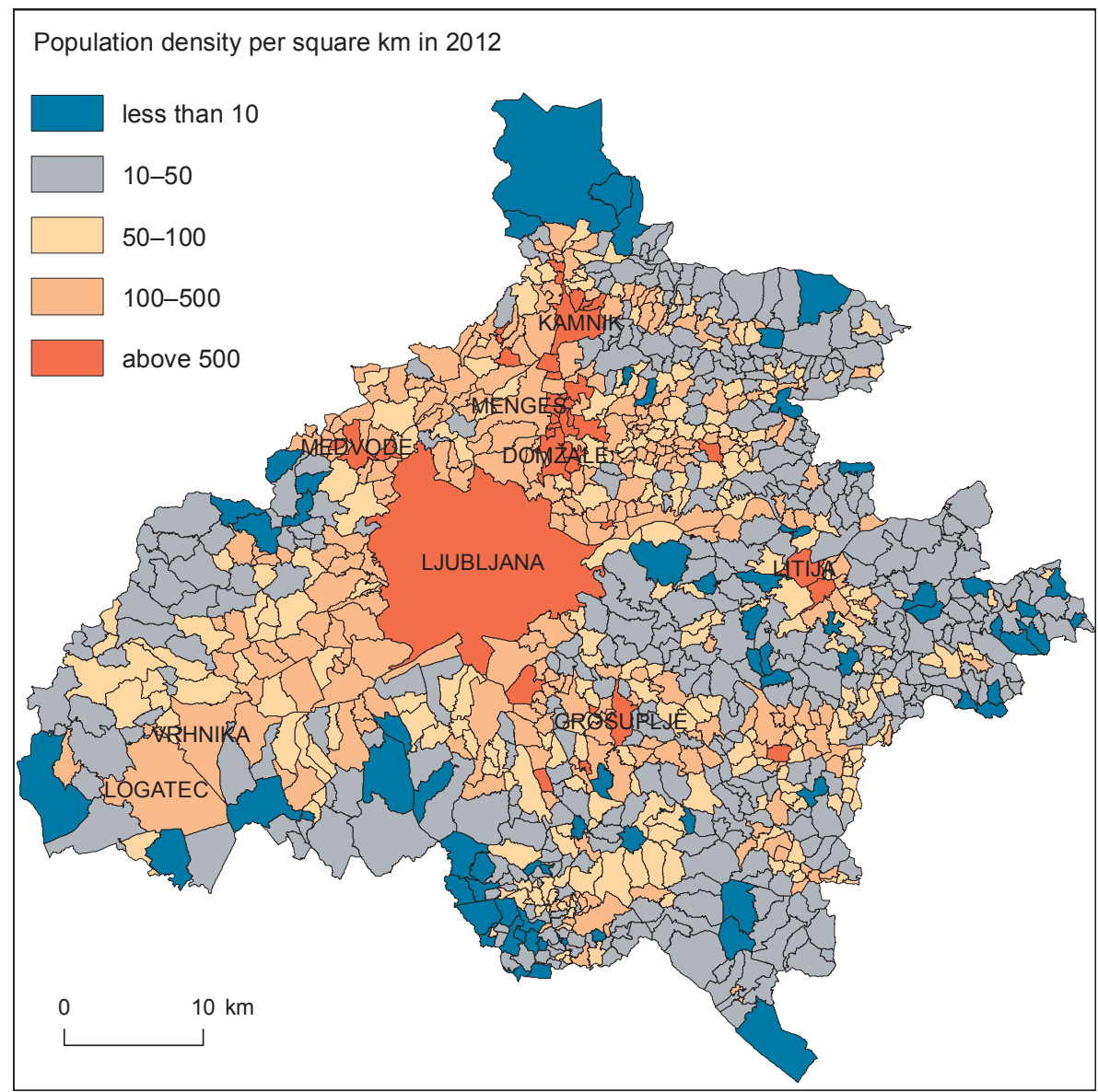

Sources/Vira: Statistical Office of the Republic of Slovenia, 2012; Statistical yearbook 2012, 2012 
The Ljubljana Urban Region (LUR) shows the fastest population growth of all Slovenian regions. From 1995 to 2011 the population in the region grew from 485,000 to 535,000 , for an increase of about $10 \%$. Population growth was especially intensive between 2005 and 2010, when it increased by 42,000 people (Statistical yearbook 2012, 2012). LUR is also the most densely populated region in Slovenia (141 inhabitants $/ \mathrm{km}^{2}$ ) with more than $25 \%$ of Slovene population (2012). LUR is therefore the largest area of concentration of population in the country. Around Ljubljana, suburbanised area with a population of approximately 200,000 formed.

LUR is a predominantly monocentric urban region with a strong central urban area. In Ljubljana, around 275,000 or $55 \%$ of the whole population of the region is concentrated. Apart Ljubljana there are six small 'satellite' towns (Kamnik, Domžale, Vrhnika, Logatec, Litija and Grosuplje) and several urbanised settlements with more than 2,000 inhabitants (Medvode, Mengeš, Trzin, Škofljica, Ivančna Gorica, Brezovica, Ig) in the region. Region is composed of 25 municipalities. Concentration in Ljubljana is even more pronounced in the case of employment. In 2012, Ljubljana had around 200,000 work places (180,000 in 2005), compared to 270,00 in LUR and 792,000 in Slovenia. Such spatial concentration of employment in Ljubljana is causing intensive commuting and all related negative effects.

The main concentration of population developed along major transport axes in direction of Vrhnika, Medvode, Domžale, Kamnik and Grosuplje and in the rest of lowlying Ljubljana Basin. Much smaller population density is characteristic for the hilly rural parts of the region (Sava Hills in the east and Polhov Gradec Hills in the west). The largest area of population concentration developed in the northeastern part of the region between Domžale and Kamnik, on Kamniška Bistrica plain. This is the largest area of suburbanisation in Slovenia. Other areas with above-average population density formed on the northern edge of Ljubljana Marsh between Ljubljana and Vrhnika and between Ljubljana and Grosuplje. In these areas the population density is between 250 and 500 inhabitants per $\mathrm{km}^{2}$. In rural areas dispersed settlement with low population density (less than 50 inhabitants per $\mathrm{km}^{2}$ ) is characteristic. Population distribution in the region is thus influenced mainly by relief and transport network.

\section{POPULATION DEVELOPMENT IN LJUBLJANA URBAN REGION BEFORE 2002}

Ljubljana Urban Region is the largest urban region in Slovenia with a constant population growth after 1945. Number of inhabitants on the territory of LUR grew from around 123,000 in 1948 to 470,651 in 1991 and 488,364 in 2002. Fast population growth in LUR is the result of migration flows in Slovenia and former Yugoslavia after the Second World War. Population growth was particularly strong in the period between the beginning of the 1950s and the end of the 1980s when 'classical' urbanisation with strong rural-urban migrations was the characteristic. 
LUR is the region with the best development possibilities in Slovenia. The most important development advantages are human capital with concentration of highly qualified work force, very favorable geographical position and accessibility, high quality of life and environment, economic structure and characteristics, availability of capital and research and development expenditure. Very important development opportunity is integration of Slovenia in European Union and as a consequence increased regional and international role and importance of Ljubljana and whole urban region. Less favorable is development potential of labor intensive industry and general low export orientation of economy (Rebernik, 2003).

Table 1: Population change on the territory of Ljubljana Urban Municipality (LUM) and LUR (Ljubljana Urban Region) between 1948 and 2011

Preglednica 1: Razvoj prebivalstva na območju Mestne občine Ljubljana (MOL) in Ljubljanske urbane regije (LUR) med letoma 1948 in 2011

\begin{tabular}{|l|c|c|r|r|r|r|}
\cline { 2 - 7 } \multicolumn{1}{c|}{} & $\mathbf{1 9 4 8}$ & $\mathbf{1 9 7 1}$ & $\mathbf{1 9 9 1}$ & $\mathbf{2 0 0 2}$ & $\mathbf{2 0 0 5}$ & $\mathbf{2 0 1 1}$ \\
\hline LUM & 123,149 & 218,081 & 272,650 & 265,881 & 266,935 & 279,898 \\
\hline LUR & 251,532 & 373,424 & 470,651 & 488,364 & 498,378 & 534,807 \\
\hline \% LUR/SLO & 17.4 & 21.6 & 23.9 & 24.7 & 24.8 & 26.0 \\
\hline \% LUM/LUR & 48.9 & 58.4 & 57.9 & 54.4 & 53.5 & 52.3 \\
\hline
\end{tabular}

Sources/Vira: Rebernik, 1999; Statistical Office of the Republic of Slovenia, 2012

Before 1991, strong migration flows were directed mainly to Ljubljana and some other employment centers in the region. A large part of population growth was thus concentrated in Ljubljana, whereas in the rest of the region population growth was considerably slower. The population on the territory of LUM increased from around 123,000 in 1948 to 218,000 in 1971 and 272,000 in 1991 (Rebernik, 1999). Around two thirds of migrants came from the rural parts of Slovenia and one third from other republics of former Yugoslavia, mostly from Bosnia and Herzegovina and parts of Croatia and Serbia (Rebernik, 1999).

The development of population in the rest of LUR was much slower than in Ljubljana till 1981, except for 'satellite towns' like Domžale, Vrhnika, Medvode, Litija and Grosuplje. In predominantly rural and sparsely populated parts of the region, decline of population was present as the consequence of rural-urban migrations. On the account of suburbanisation, the population began to grow in the first suburban belt around the city after 1971. This growth was most pronounced in the northern and western outskirts. In the decade between 1981 and 1991, suburbanisation became even more intense and suburbanised settlements between Ljubljana, Domžale, Kamnik, Medvode, Vrhnika and Grosuplje recorded the fastest annual population growth rates in Slovenia (5-10\%). The largest suburbanised area in Slovenia with over 150,000 inhabitants or one third of population of the whole LUR developed in this way. 
Figure 2: Population development in Ljubljana Urban Region between 1991 and 2002 by settlements

Slika 2: Razvoj prebivalstva v Ljubljanski urbani regiji med letoma 1991 in 2002 po naseljih

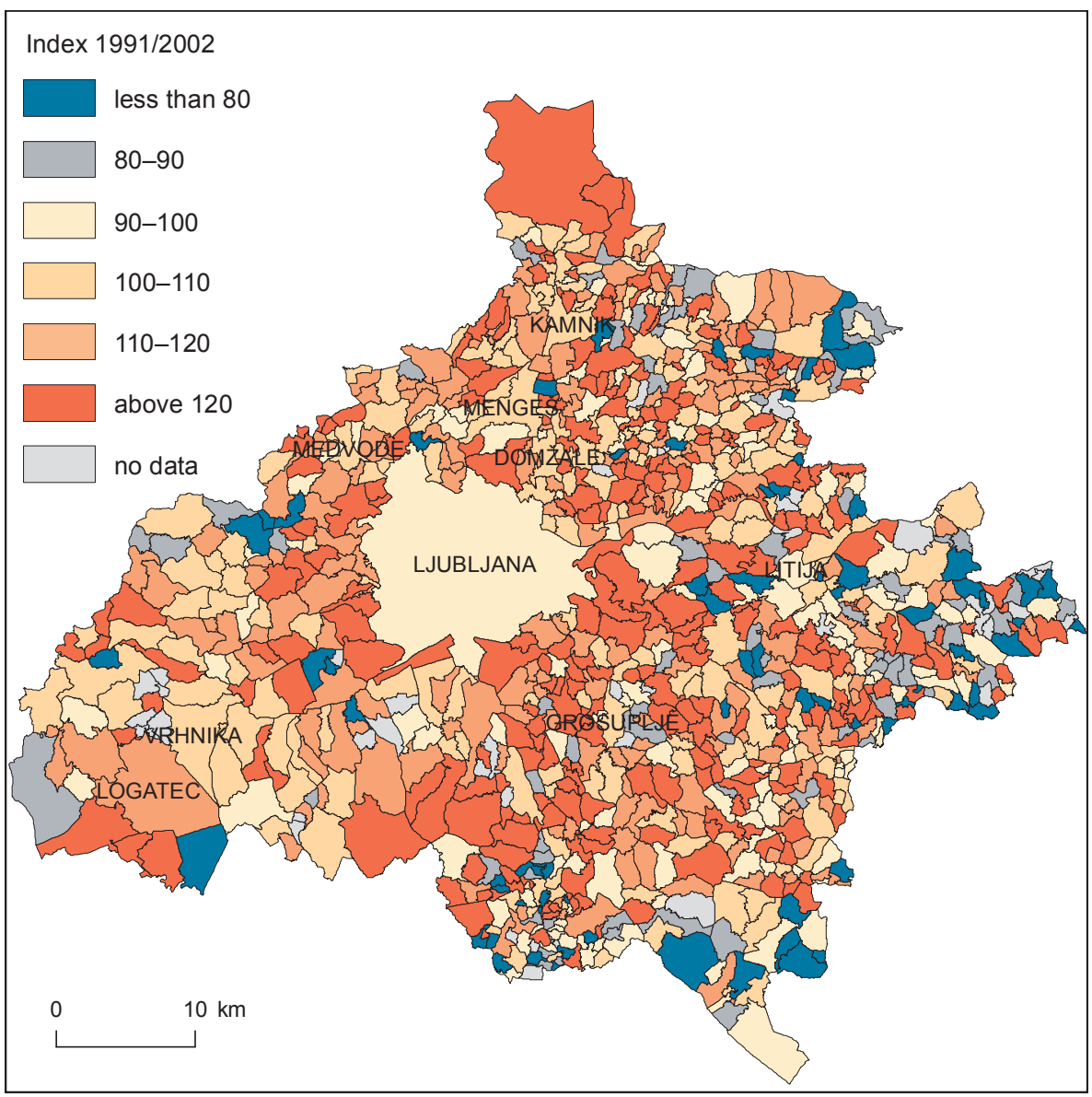

Source/Vir: Statistical Office of the Republic of Slovenia, 2012

LUR remained an area of immigration after 1991 as well. Between 1991 and 2002 the total population of the region increased for 5.0\% against $2.0 \%$ in whole Slovenia. Migrations were predominantly economical and the consequence of better employment possibilities and a wider range of jobs in LUR than in the rest of Slovenia. In the 1990s, important changes in the population distribution and urbanisation trends occurred in the region. Deconcentration of population from Ljubljana to the periphery of the region continued with increased intensity. The population of Ljubljana decreased for 9,000 or $3.5 \%$ between 1991 and 2002, whereas all other municipalities in the region recorded above-average population growth (Rebernik, 2003). All other municipalities had posi- 
tive net migration, the highest being in municipalities of Domžale, Grosuplje, Ivančna Gorica, Medvode, Škofljica and Trzin. In the second half of the 1990s, the highest population growth was recorded in small rural settlements. The area of population growth extended to whole LUR and included rural parts of the region as well. Small rural settlements, mostly in the southern, eastern and northeastern part of the region had the highest population growth.

\section{POPULATION DEVELOPMENT AND URBANISATION TRENDS IN LJUBLJANA URBAN REGION AFTER 2002}

Fast population growth in LUR continued after 2002 as well. In the decade between 2002 and 2012, the number of inhabitants grew for $10 \%$ to 537,712 in 2012. Aboveaverage population growth in the region was a consequence of positive net migration and natural population growth.

Table 2: Natural population growth and net migration in Ljubljana Urban Region (LUR) and Slovenia (SLO) between 2002 and 2011 (\%o)

Preglednica 2: Naravna rast prebivalstva in neto migracije $v$ Ljubljanski urbani regiji (LUR) in v Sloveniji (SLO) med letoma 2002 in 2011 (\%)

\begin{tabular}{|l|c|c|c|c|c|c|c|c|c|c|}
\cline { 2 - 11 } \multicolumn{1}{c|}{} & $\mathbf{2 0 0 2}$ & $\mathbf{2 0 0 3}$ & $\mathbf{2 0 0 4}$ & $\mathbf{2 0 0 5}$ & $\mathbf{2 0 0 6}$ & $\mathbf{2 0 0 7}$ & $\mathbf{2 0 0 8}$ & $\mathbf{2 0 0 9}$ & $\mathbf{2 0 1 0}$ & $\mathbf{2 0 1 1}$ \\
\hline $\begin{array}{l}\text { Natural population } \\
\text { growth LUR }\end{array}$ & 1.1 & 0.6 & 1.4 & 1.6 & 2.4 & 3.0 & 4.3 & 4.1 & 4.3 & 4.1 \\
\hline Net migration LUR & 1.2 & 2.6 & 2.6 & 5.0 & 4.4 & 9.0 & 21.7 & 13.6 & 2.3 & 2.0 \\
\hline $\begin{array}{l}\text { Natural population } \\
\text { growth SLO }\end{array}$ & -0.6 & -1.0 & -0.3 & 0.3 & 0.4 & 0.6 & 1.7 & 1.6 & 1.8 & 1.6 \\
\hline Net migration SLO & 0.9 & 1.7 & 1.0 & 3.2 & 4.2 & 7.0 & 9.1 & 5.6 & -0.3 & 1.0 \\
\hline
\end{tabular}

Sources/Vira: Statistical Office of the Republic of Slovenia, 2012; Statistical yearbook 2012, 2012

In the decade between 2002 and 2011, natural population growth and net migration in LUR were positive and higher than in Slovenia. As a result of younger population (index of ageing in Slovenia in 2011 was 116 and 106 in LUR), natural population growth was above Slovenian average in observed period. About $40 \%$ of population growth in LUR was the result of natural population growth and around $60 \%$ was the consequence of positive net migration. Due to favorable economic situation, immigration into LUR was particularly intense between 2007 and 2009. 
Figure 3: Population development in Ljubljana Urban Region between 2002 and 2011 by municipalities

Slika 3: Razvoj prebivalstva v Ljubljanski urbani regiji med letoma 2002 in 2011 po občinah

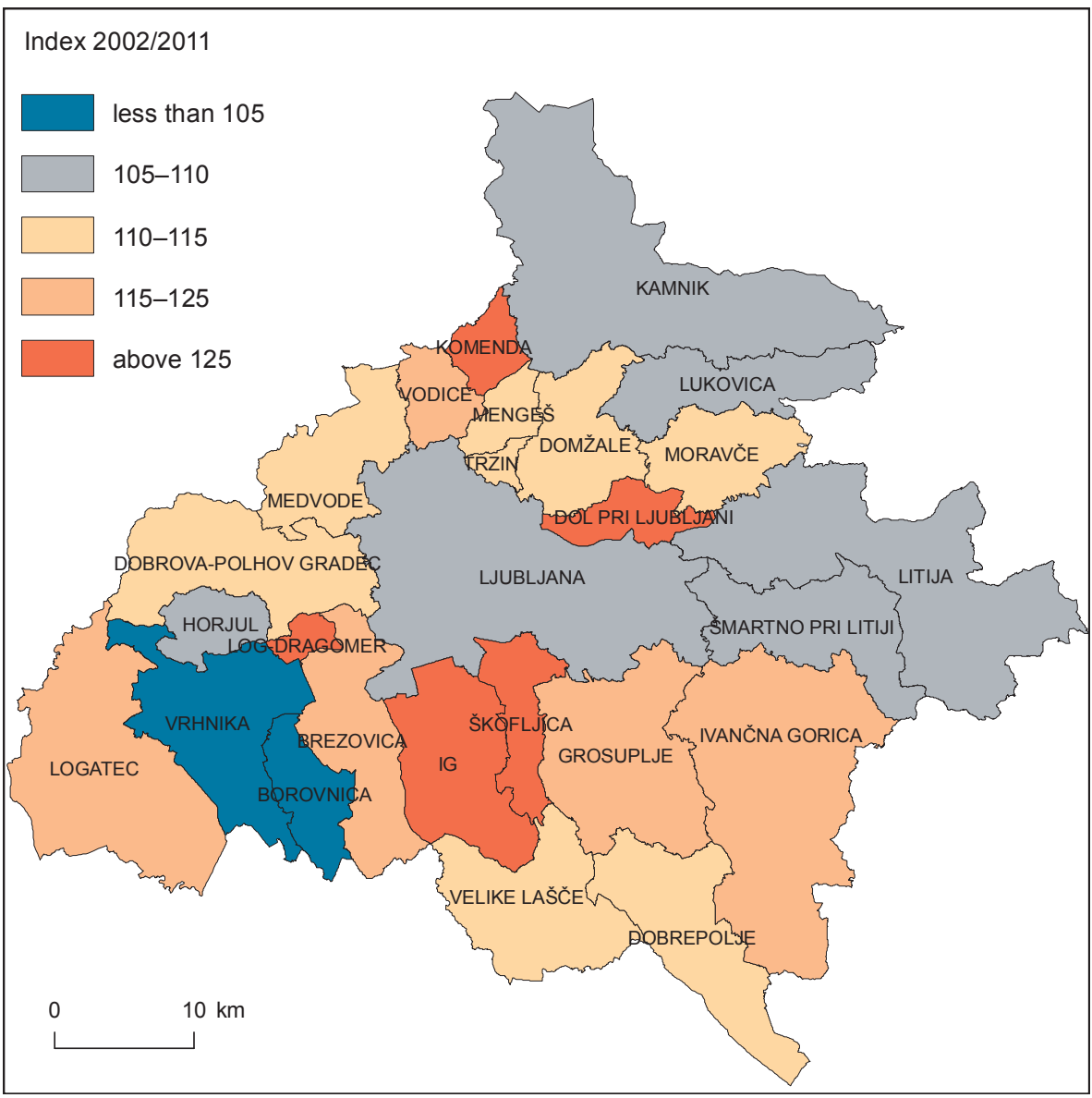

Sources/Vira: Statistical Office of the Republic of Slovenia, 2012; Statistical yearbook 2012, 2012 
Figure 4: Population development in LUR between 2002 and 2012 by settlements Slika 4: Razvoj prebivalstva v Ljubljanski urbani regiji med letoma 2002 in 2011 po naseljih

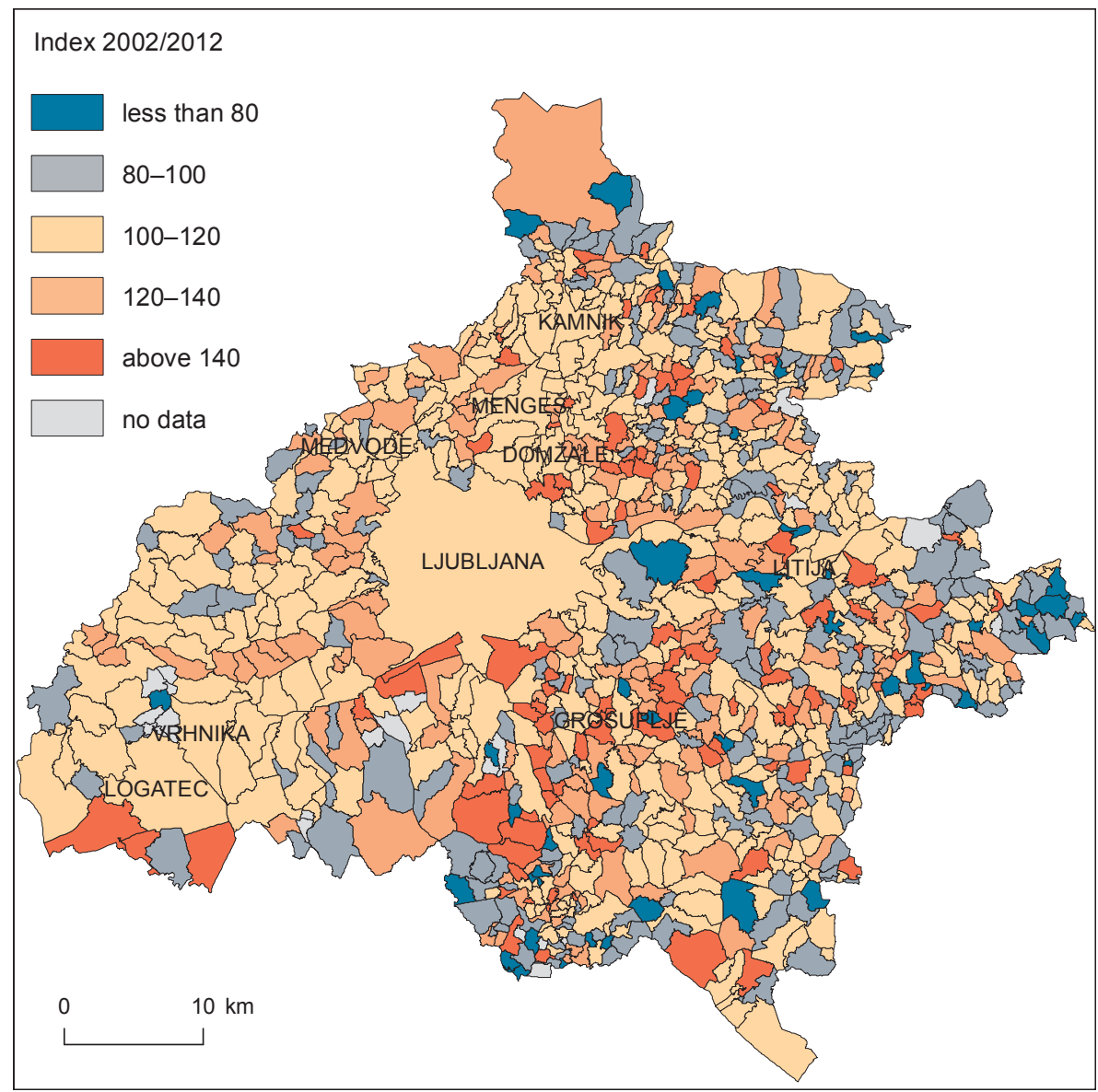

Source/Vir: Statistical Office of the Republic of Slovenia, 2012

Population growth in suburban as well as in some rural settlements in the region continued after 2002 as well. Of all the municipalities in the region, the population declined from 2002-2011 only in the municipalities of Litija and Vrhnika. The largest contiguous area of rapid population growth after 2002 took shape in the southern part of LUR, between the municipality of Brezovica in the west and the municipality of Grosuplje in the east. These are typical suburban municipalities which include the southern suburbanised settlements of Ljubljana and in part also rural settlements in the area of the Ljubljana Marsh and the hills along its edges (Polhov Gradec, Krim, and Sava Hills). Fast population growth was recorded in municipalities of Logatec in southwestern and municipalities Dol pri Ljubljani, Vodice and Komenda in the northern part of the region as well. 
Based on the methodology developed by Ravbar (1997; 2002), settlements in LUR can be divided into four types: towns, nearby suburbs, suburbanised settlements and rural settlements. This typology is based on three main criteria: socio-economic, physiognomic, and functional (Ravbar, 1997). In 2000, about three-fifths of the population (around 300,000 inhabitants) lived in Ljubljana and other towns, about 140,000 in suburban settlements, and about 70,000 inhabitants in rural settlements (Ravbar, 2002).

Beside Ljubljana there are seven urban settlements in the region. All can be classified as typical 'satellite towns' with strong functional connections with Ljubljana. One of the main characteristics of satellite towns is a deficit of workplaces compared to active population and poorly developed service activities. Large part of inhabitants of satellite towns is commuting to Ljubljana. All towns in the region except Litija experienced population growth in observed period. Population growth in satellite towns is mainly a consequence of positive net migration due to considerably lower prices of housing than in Ljubljana.

Table 3: Number of inhabitants and index of population change in towns of LUR between 2002 and 2012

Preglednica 3: Število prebivalcev in indeks razvoja prebivalstva $v$ mestnih naseljih $v$ LUR med letoma 2002 in 2012

\begin{tabular}{|l|l|l|l|l|l|l|}
\cline { 2 - 7 } \multicolumn{1}{c|}{} & Domžale & Grosuplje & Kamnik & Litija & Logatec & Vrhnika \\
\hline Population 2012 & 12,588 & 7,174 & 13,608 & 6,458 & 9,091 & 8,454 \\
\hline $2002 / 2012$ & 108 & 118 & 111 & 100 & 119 & 112 \\
\hline
\end{tabular}

Sources/Vira: Statistical Office of the Republic of Slovenia, 2012; Statistical yearbook 2012, 2012

From 2005 to 2012, the Ljubljana Urban Municipality (LUM) recorded population growth again after a relatively long period of declining population size as well. The number of inhabitants in the LUM increased from 267,000 in 2005 to 280,000 in 2012, or by about $5 \%$. This increase was due mainly to growth in housing construction and consequently a greater supply of housing in the city of Ljubljana. Along with the process of suburbanisation and periurbanisation, there was also reurbanisation in the region. As the model of the urbanisation cycle explains (Champion, 2001; Rebernik, 2008), every urban region experience four phases of urbanisation (urbanisation - suburbanisation - deurbanisation - reurbanisation), which are determined on the basis of direction and intensity of migrations between the city, the suburbs, and rural areas. Several processes can take place simultaneously in the same region, which is the case of LUR as well (Rebernik, 2008).

The city of Ljubljana is surrounded by nearby suburbs and suburbanised settlements. The settlements in the nearby suburbs are spatially contiguous with the city whereas suburbanised settlements developed along main transport axes in the low-lying Ljubljana Basin. The housing construction is typically relatively dense and consists mainly of one- and twofamily dwellings. Population density in this area is higher than 500 inhabitants per $\mathrm{km}^{2}$ and is comparable with urban regions in Western and Central Europe (Ravbar, 2002). 
Settlements in nearby suburbs and suburbanised settlements continued to experience population growth after 2002, which is particularly true for southern (Brezovica, Lavrica, Škofljica) and western suburbs (Dobrova, Golo Brdo). But, it has to be stressed that in comparison with previous decade population growth slowed down considerably. Older suburbs thus experience less intensive population growth which is a common characteristic of most urban regions in Europe. Besides having a residential function, the settlements are also hosting certain service and production activities. These are located mainly along the main roads (Tržaška, Dolenjska, Celovška and Štajerska roads), and also in business and industrial zones (Trzin, Škofljica and others).

A comparison of satellite images for the years 2003 and 2011 shows that the spatial expansion of settlements during this period was limited to filling-in empty spaces inside or at the edge of existing settlements in the form of internal development of settlements. The process of development and expansion of settlements is thus to some extent in accordance with national strategic guidelines. In this way a contiguous area of settlements with relatively high population density has taken shape between the settlements of Trzin and Domžale in the northwestern, between Brezovica, Notranje Gorice and Vnanje Gorice in the southwestern and between Lavrica and Škofljica in the southeastern part of the region. Due to expansion, settlements have been spatially joined together into an unified suburbanised area.

If individual do-it-yourself construction of houses was typical of the period until 1995, after that year new forms of housing construction appeared. Especially characteristic was housing construction for the market in the form of relatively small, closed groups of one-family dwellings with common architectural and urban planning designs. Smaller groups of houses (10 to 20 housing units) predominated, usually row houses. Common parking areas, street lighting, and green spaces were also provided. Such smaller groups of housing units represent a new element in suburbanised settlements. They bring a more urban character into settlements, including greater density of settlement. In this respect, this kind of development of suburbanised settlements represents a positive shift towards the internal development of settlements and the improvement of areas with dispersed settlement. In all the settlements in the nearby suburbanised areas, stand-alone one-family houses strongly predominated. Multi-family housing construction, which is otherwise typical of urban settlements, has also begun to appear in some suburbanised settlements. Where these neighborhoods are appropriately planned and integrated into the existing settlement, they represent a qualitative leap in the spatial development of suburban settlements. A larger population and greater density of settlement make possible the development of public transport and more rapid development of services. In this way settlements in the nearby suburbanised areas become a part of the greater metropolitan space.

Rural settlements in the hinterland of Ljubljana have also experienced intensive population and spatial development in the last decades. This is especially true for the period from 2002 to 2012, when some rural settlements experienced the greatest relative population growth of all settlements in the area studied. Thus the fastest population growth was characteristic of selected rural settlements in the Krim Hills in the municipalities of Škofljica, Ig, and Brezovica and in Sava Hills in the municipality of Grosuplje. Very interesting is the example of settlements on the northern slopes of Krim Hills. After 1991, the settlements in 
this area experienced very intense population and spatial development. Even before 1991, several groups of second homes took shape here. The proximity of Ljubljana (about 30 to 45 minute's drive to the city center), good road connections, a well preserved natural environment with the preponderance of forest and meadows, clean air, and favorable climatic conditions with a smaller number of foggy days than in the Ljubljana Basin as well as the relatively low cost of land were factors contributing to the creation of colonies of second homes. The settlement of second homes Rakitna stands out in particular due to its size; smaller such settlements are Gradišče nad Pijavo Gorico, Golo, Zapotok, and Visoko.

In these settlements of second homes there has been an interesting process of partial transformation into permanent residences. In many cases, the members of the older gen-

Figure 5: Index of ageing in LUR by settlement (2012)

Slika 5: Indeks staranja $v$ LUR po naseljih (2012)

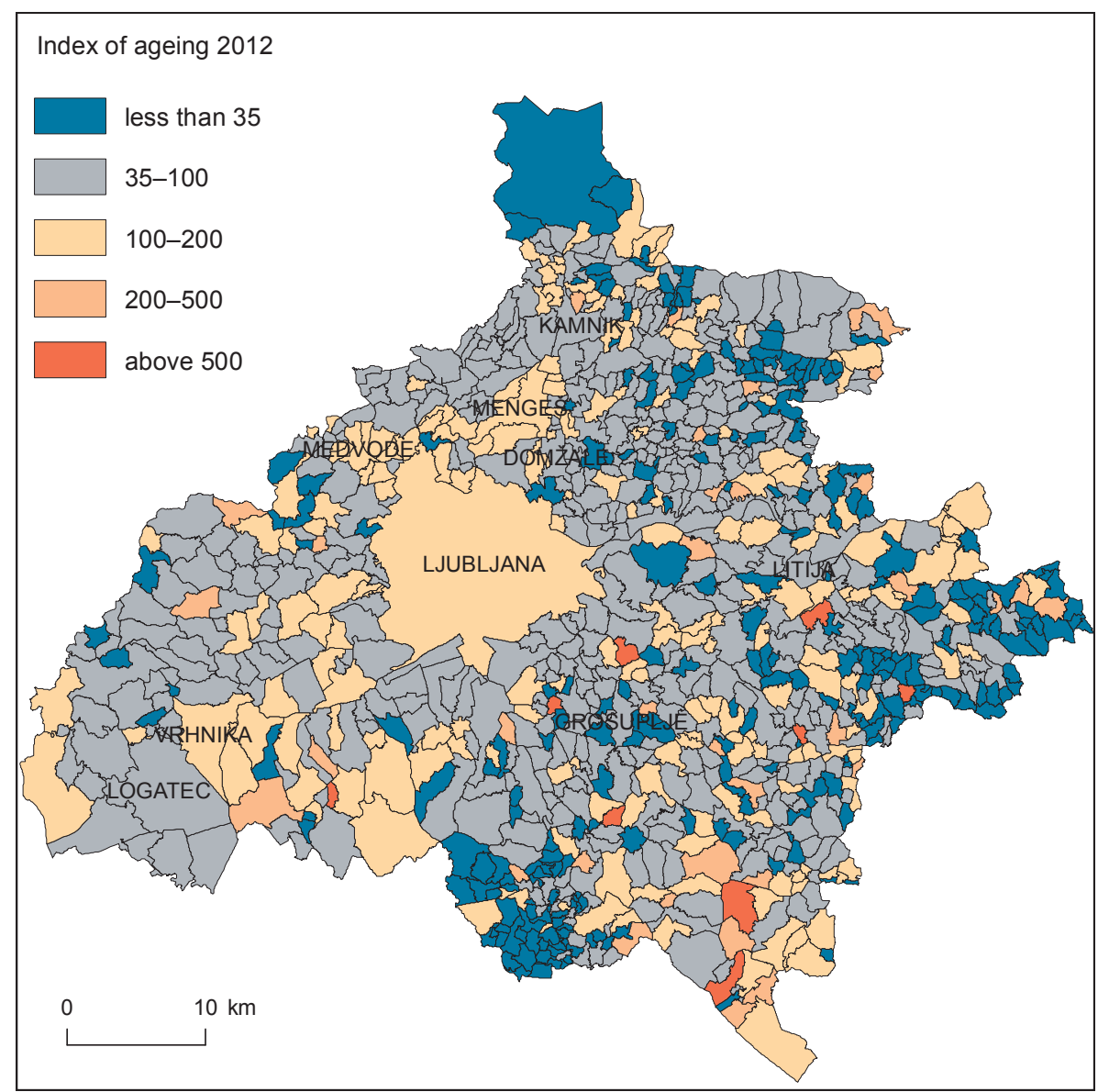

Source/Vir: Statistical Office of the Republic of Slovenia, 2012 
eration have moved permanently into what used to be a second home, leaving the flat in the city to their adult children. The individual construction of one-family houses predominated in all rural settlements in the region. The development of settlements was chaotic, with sprawling construction of houses at the edge of, or outside settlements being quite common. The settlements are surrounded by forest and agricultural land, and set far apart from one another. Housing construction was left entirely to the tastes of investors; hence the appearance of the settlements is highly disparate. Areas of newer construction developed around older parts, and part of the new construction, most often as smaller groups of one-family houses, is located outside existing settlements. After 2000, more organised

Figure 6: Average size of households by settlement (2011)

Slika 6: Povprečna velikost gospodinjstev po naseljih (2011)

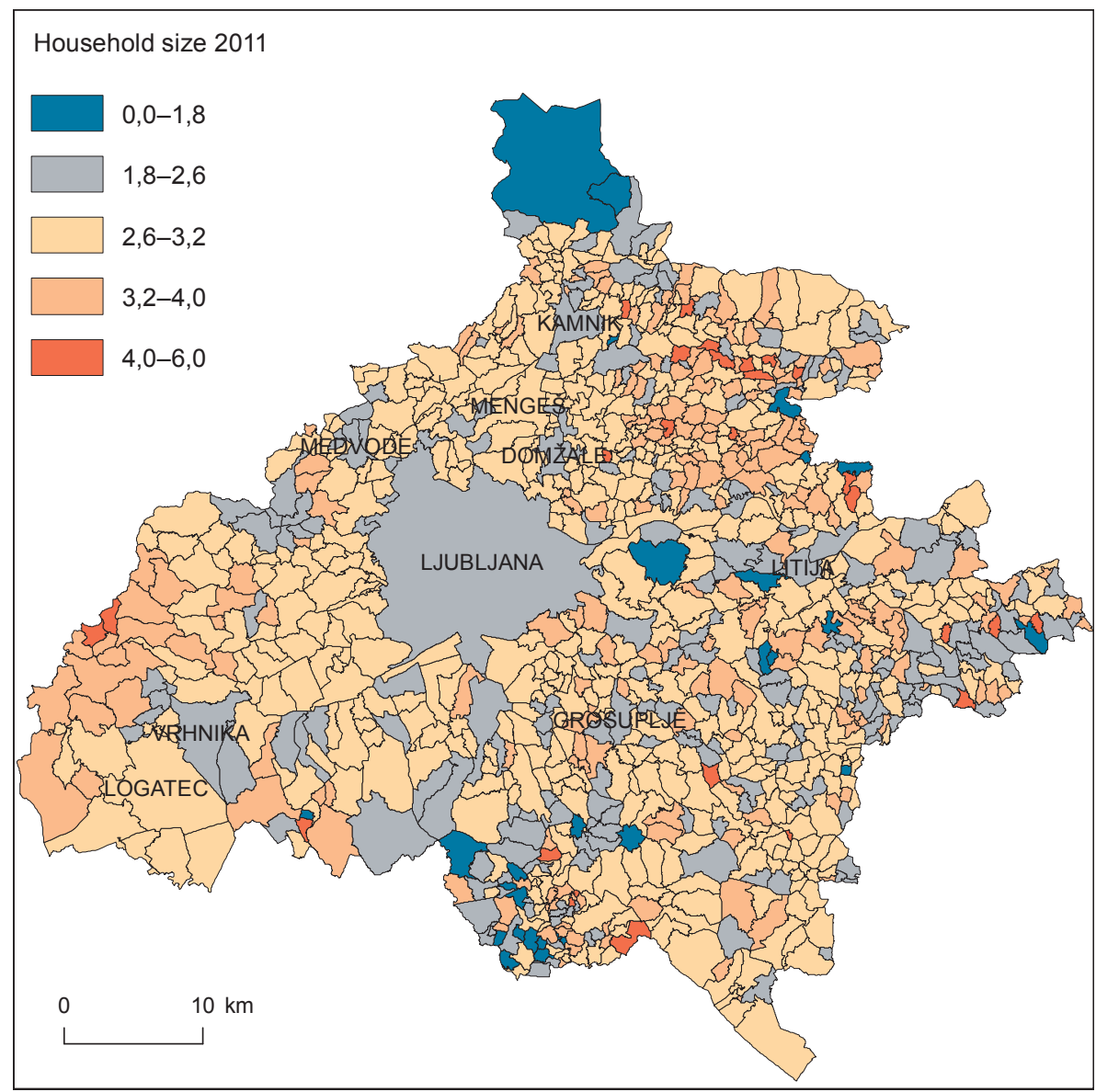

Source/Vir: Statistical Office of the Republic of Slovenia, 2012 
construction also appeared in these settlements. Individual investors built smaller groups of row houses, and in some places even smaller apartment blocks.

There are marked differences in age structure of population in urban, suburban and rural settlements (Figure 5). As expected, older population (index of ageing above 100) and smaller households are characteristic for urban settlements, particularly Ljubljana. For suburban settlements on the other hand, larger households and younger population are typical. The age and households structure is a reflexion of internal migration flows. Young and middle-aged families with children are most likely to move from Ljubljana and other urban settlements to suburban or rural settlements. The youngest population

Figure 7: Share of the population with higher education by settlements (2011)

Slika 7: Delež prebivalcev z visoko izobrazbo po naseljih (2011)

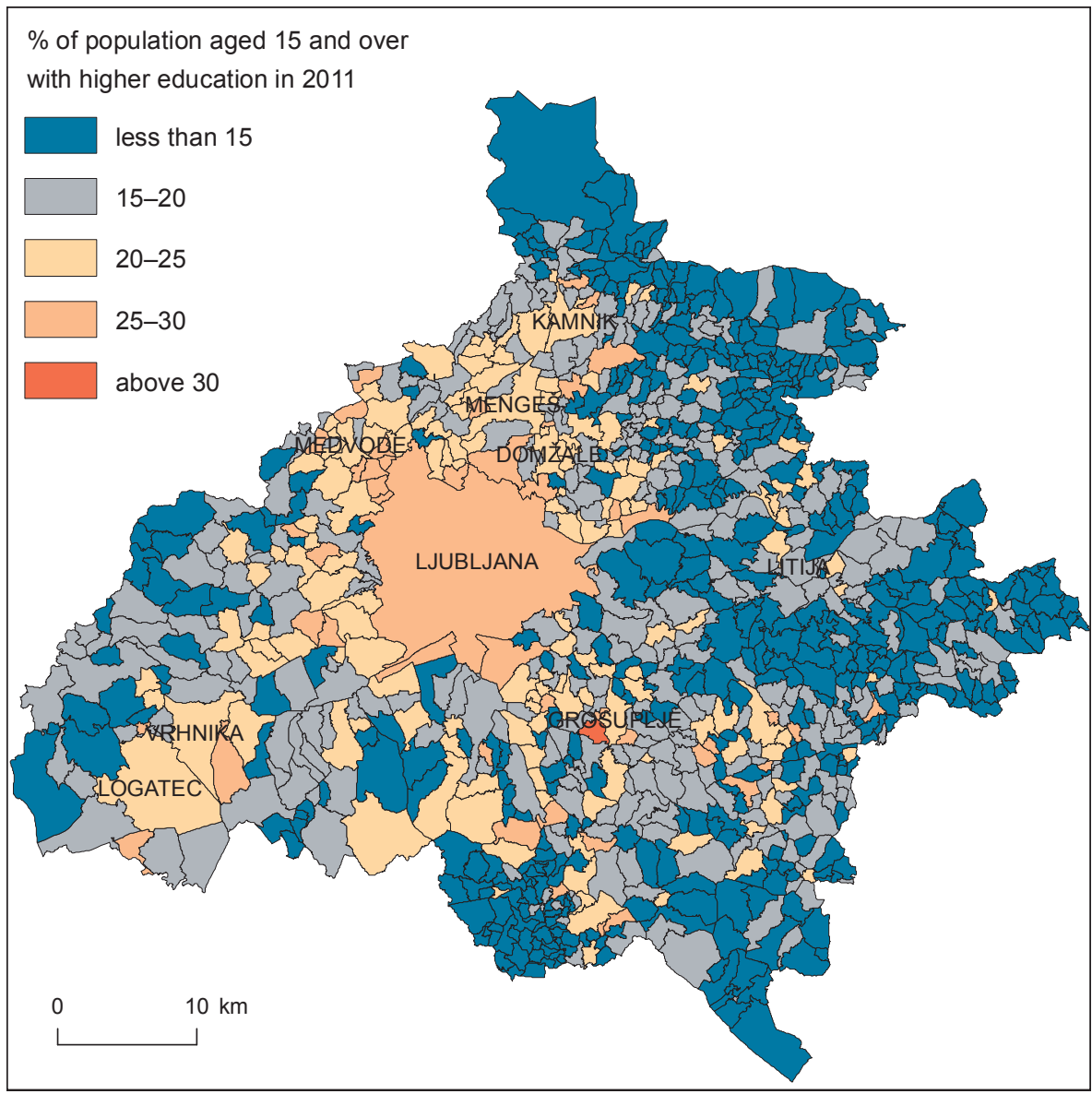

Source/Vir: Statistical Office of the Republic of Slovenia, 2012 
and predominance of families with children is thus characteristic for suburban and rural settlements with the highest population growth in the last period. In older suburbs, which had the highest population growth in the 1980s and 1990s, middle-aged and older households predominate.

There are marked differences in socio-economic structure of population between urban, suburban and rural settlements as well. Much higher share of population with high education is thus characteristic for urban and most of suburban settlements in comparison with rural settlements (Figure 7). Exceptions are rural settlements which experienced intensive immigration of population from urban settlements in the last decade. Due to the influx of younger and better educated people from Ljubljana, the population of these settlements is relatively young and well educated, in contrast to other rural areas in the region and in Slovenia. The index of ageing is lower than 100, and the share of the population with higher education exceeds $20 \%$. In this way, there has been a very interesting socio-economic transformation of these settlements. They have acquired an entirely new function as the residential environment of a population employed in Ljubljana and living a more or less urban way of life. This is reflected in the external appearance of settlements and architecture of new construction that is entirely 'urban'. New construction with modern architecture predominates, and the size of houses shows the high socio-economic position of new residents.

\section{CONCLUSION}

The Ljubljana Urban Region (LUR) remains the Slovenian region with the fastest growing population, which is primarily a result of a positive migration balance, and in more recent years also as a result of positive natural increase. Also within the region, there has been a relatively intense migration of the population between cities, suburbanised settlements, and rural areas. Over the past thirty years, the main process has been the migration of the population from cities to suburbs. In this way the largest area of suburbanisation in Slovenia has taken shape in the greater vicinity of Ljubljana.

Based on the results of this research, we can confirm that there were important changes in migration trends after 1990, and these were especially pronounced after 2000 . The fastest relative population growth was thus experienced by some rural settlements, especially those in the hilly southern and eastern parts of the region. Classical suburbanisation with population growth in the nearby suburbs has during the past decade given way to periurbanisation, for which intensive population growth in rural settlements is typical. The in-migration of the population into these settlements is predominantly the result of relatively good accessibility to Ljubljana, the lower costs of building land than in the city and suburban settlements, and a better quality residential environment.

The spatial development of rural settlements with intensive population growth follows the model of sprawling construction in the form of smaller groups of one-family dwellings at the edge of existing settlements or entirely outside the areas of compact settlements. This kind of spatial development of settlements exacerbates the negative impacts associated with sprawl: longer commutes, less use of public transport, irrational 
land use, high costs of building and maintaining municipal and transportation infrastructure, and similar. We should also note the great gap between the strategic guidelines for spatial development at the national and the local (municipal) levels.

On the other hand, there has been an internal development of settlements and increased density of settlement in the nearby suburbs. Besides individual residential construction of one-family dwellings, there has also been organised residential construction of smaller multi-family dwellings or row houses in the last ten years. In this way suburbanised settlements have become integral parts of wider urban areas. Employment on the other hand remains concentrated in Ljubljana and in lesser extent in other urban employment centers. As a consequence, intense daily migrations and resulting traffic are characteristic. This kind of development is one of the main reasons for decreasing share of public transport. The use of private car that represent almost $90 \%$ of trips in the urban area of Ljubljana is causing a lot of traffic and environmental problems and is in sharp contrast with declared sustainable development of the city and urban region.

The main reasons for intensive suburbanisation in Slovenia and in LUR are similar to those in the countries of Western Europe, but several specific factors connected to different political and socio-economic system influenced the suburbanisation as well: lack and high prices of housing and building plots in urban areas, relatively low price of building plots and infrastructure on the outskirts of urban areas, liberal access to building plots, preference of one-family housing with private gardens, lower costs and higher quality of living in suburban areas, improved accessibility due to new roads and increased car ownership, poor urban planning and lack of effective control of urbanisation and widespread illegal construction. Most of new housing in suburban areas was built as so called 'individual' construction, carried out by owners of building plots with the help of family, friends and building companies. As a result, new housing is extremely dispersed, often poorly designed, with standard 'urban' type of one family houses being constructed in all Slovene regions (Rebernik, 2005).

\section{(Translated by the author)}

\section{References}

Champion, A., 2001. Urbanization, suburbanization, counterurbanization and reurbanization. In: R. Padison (Ed.). Handbook of urban studies. London, SAGE Publication, p. 142-161. URL: http://upenn-envs667660.webs.com/Readings/Urbanization\%20 Suburbanization\%20Counterurbanization\%20and\%20Reurbanization \%20-\%20 Champion.pdf (Cited 20. 5. 2012).

Ravbar, M., 1995. Zasnova poselitve Slovenije. Inštitut za geografijo, Ljubljana.

Ravbar, M., 1997. Slovene cities and suburbs in transformation. Geografski zbornik, 37, p. 65-109.

Ravbar, M., 2002. Suburbanizacijske težnje v razvoju prebivalstva in delovnih mest v Ljubljanski mestni regiji. V: Pak, M. (ur.). Geografija Ljubljane. Ljubljana, Oddelek za geografijo Filozofske fakultete, p. 215-233. 
Rebernik, D., 1999. Prebivalstveni razvoj Ljubljane po letu 1945. Geografski vestnik, 71, p. 41-60.

Rebernik, D., 2003. Ljubljana urban region - development trends, problems and possibilities. Dela, 19, p. 165-175. URL: http://revije.ff.uni-lj.si/Dela/article/view/1401/1205 (Cited 20. 5. 2012).

Rebernik, D., 2005. Urbanisation trends and processes of population change in the Ljubljana Urban Region in the 1990s. Geographica Polonica, 78, 1, p. 67-78.

Rebernik, D., 2008. Urbana geografija: geografske značilnosti mest in urbanizacije v svetu. Ljubljana, Znanstveni inštitut Filozofske fakultete, 294 str.

Rebernik, D., Krevs, M., 2013. Spatial and demographic development of settlements in the southern part of the Ljubljana Urban Region. Dela, 40, p. 91-116. DOI: 10.4312/ dela.40.6.91-116

Statistical Office of the Republic of Slovenia. 2012. SI-Stat Data Portal. URL: http:// pxweb.stat.si/pxweb/Dialog/statfile1.asp (Cited 20. 5. 2012).

Statistical yearbook 2012. 2012. Ljubljana, Statistical Office of the Republic of Slovenia. URL: http://www.stat.si/letopis/LetopisPrvaStran.aspx?leto=2012\&jezik=si (Cited 20. 5. 2012).

Uredba o standardni klasifikaciji teritorialnih enot (Decree on the standard classification of territorial units). 2007. Uradni list RS, 9 (2. 2. 2007). URL: http://www.pisrs.si/Pis. web/pregledPredpisa?id=URED4094 (Cited 20. 5. 2012).

\section{RAZVOJ PREBIVALSTVA IN URBANIZACIJSKI PROCESIV LJUBLJANSKI URBANI REGIJI PO LETU 2002}

\section{Povzetek}

Glavni namen prispevka je podati in predstaviti poglavitne značilnosti prebivalstvenega in prostorskega razvoja naselij ter značilnosti urbanizacije v Ljubljanski urbani regiji (LUR) po letu 2002. Na osnovi tipologije naselij glede na značilnosti urbanizacije, ki jo je razvil Ravbar (1997), lahko regijo razdelimo na mesta, bližnja obmestja, suburbanizirana naselja in ruralna naselja. $\mathrm{V}$ raziskavi smo poskušali ugotoviti, ali so med tako opredeljenimi naselji razlike v prebivalstvenem in prostorskem razvoju. Zanimalo nas je tudi, ali je prišlo do pomembnejših razlik v razvoju prebivalstva v primerjavi z obdobjem pred letom 2002. Ker v Sloveniji spremlja suburbanizacijo tudi morfološka, funkcijska in socio-ekonomska preobrazba naselij, smo poskušali opredeliti tudi osnovne značilnosti preobrazbe naselij pod vplivom suburbanizacije.

LUR je ena izmed dvanajstih slovenskih razvojnih oziroma statističnih regij, kot so bile določene z Odlokom o standardni klasifikaciji teritorialnih enot. Gre za največjo urbano regijo v Sloveniji s stalnim trendom naraščanja števila prebivalstva po letu 1945. Število prebivalcev na območju današnje LUR je naraslo od približno 123.000 v letu 1948 na 470.651 v letu 1991 in 488.364 v letu 2002. Hitra rast prebivalstva je predvsem posledica priseljevanja prebivalstva iz ruralnih območij Slovenije in republik bivše Jugoslavije. Rast prebivalstva je bila še posebno intenzivna od začetka 50. do konca 80 . 
let, v času 'klasične' urbanizacije z močnimi ruralno-urbanimi migracijami. LUR izkazuje najhitrejšo rast prebivalstva med vsemi slovenskimi regijami tudi po letu 2002. Med letoma 1995 in 2011 je prebivalstvo v regiji naraslo od 485.000 na 535.000 oziroma za $10 \%$. LUR je tudi najgosteje poseljena regija v Sloveniji $\left(141 \mathrm{preb} . / \mathrm{km}^{2}\right)$ in predstavlja največjo zgostitev prebivalstva $v$ državi.

Za LUR so značilne relativno intenzivne migracije prebivalstva med mesti, suburbaniziranimi naselji in podeželjem. V zadnjih tridesetih letih je bil poglavitni trend razseljevanje prebivalstva iz mest $v$ suburbana naselja. Na ta način se je v širši okolici Ljubljane oblikovalo največje območje suburbanizacije v Sloveniji. Na osnovi rezultatov pričujoče raziskave lahko potrdimo, da so se po letu 1990, še posebno pa po letu 2000, zgodile pomembne spremembe $\mathrm{v}$ selitvah prebivalstva znotraj regije. Največjo relativno rast prebivalstva so tako doživela ruralna naselja, še posebno tista $v$ južnem in vzhodnem hribovitem delu LUR. Klasična suburbanizacija z rastjo prebivalstva v obmestjih je tako prešla $\mathrm{v}$ periurbanizacijo, za katero je značilna rast prebivalstva $\mathrm{v}$ ruralnih naseljih. Po drugi strani je prišlo do notranjega prostorskega razvoja naselij in povečane gostote poselitve v bližnjih obmestjih. V teh naseljih se je poleg prevladujoče individualne gradnje enodružinskih hiš uveljavila tudi organizirana stranovanjska gradnja manjših skupin eno- ali večstanovanjskih hiš. $\mathrm{Na}$ ta način postaja obmestje sestavni del kompaktnega urbanega prostora.

Priseljevanje prebivalstva v omenjena naselja je v prvi vrsti posledica dobre dostopnosti do Ljubljane, nižjih cen zazidljivih zemljišč oziroma nepremičnin in višje kvalitete bivalnega okolja. Prostorski razvoj ruralnih naselij, ki doživljajo hitro rast prebivalstva, sledi modelu razpršene poselitve v obliki manjših skupin stanovanjskih hiš na robu oziroma izven obstoječih strnjenih naselij. Ta vrsta prostorskega razvoja naselij ima vse negativne posledice pojava urban sprawl: daljša dnevna potovanja, zmanjšana uporaba javnega prometa, neracionalna raba prostora ter visoki stroški izgradnje in vzdrževanja prometne in komunalne infrastrukture. 